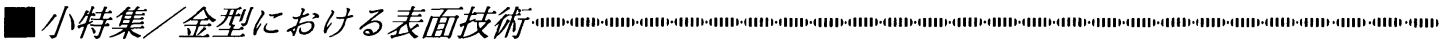

\title{
プラスチック用表面加飾成形型の開発
}

\author{
野口 裕之*, 魏杰*, 中川 威雄 ${ }^{*}$ \\ 宮本 和彦**, 柳沢 章***, 今村 正人***
}

\section{Development of Plastic Mold with Fine Surface Pattern for Polymer Forming}

Hiroyuki NOGUCHI*, Jie WEI*, Takeo NAKAGAWA* Kazuhiko MIYAMOTO**, Akira YANAGISAWA ** and Masato IMAMURA****

Key Words : Mold, Ceramic Mold, Permeable Mold

皮しぼなど微細な表面加飾のためのプラスチッ ク成形型は,これまで樹脂型, 溶射型, 鋳造型,

電鋳型が使われてきた。筆者らはセラミックスの 焼結による型やセラミックス鋳型を用いた精密鋳 造による型の開発を行ってきたが，用途によって は従来型より優れた特徴をもつ型となり得る見通 しを得た。

\section{1 、転写による表面加飾型}

プラスチック成形においては，表面を皮しぼや 布生地，木目等の仕上がりが要求される場合は少 なくない。プラスチックは転写によって成形され

* 東京大学生産技術研究所（テ106 東京都港区六 本木7-22-1)

Inst. of Ind. Sic., Univ. of Tokyo (22-1, Roppongi 7-chome, Minato-ku, Tokyo 106) **三田工業(侏）（二540 大阪府大阪市東区玉造1-228)

Mita Industrial Co., Ltd. (2-28, Tamatsukuri 1-chome, Higashi-ku, Osaka 540)

*** 日本工業大学（开345 埼玉県南埼玉郡宮代町学 園台4-1)

Nippon Inst. of Tech. (4-1, Gakuendai, Miyasiro-cho, Minamisaitama-gun, Saitama 345)

**** 新東工業攸（テ338 埼玉県浦和市西堀4-6-10）

Shinto Kogyo Co., Ltd. (6-10, Nishibori 4chome, Urawa-shi, Saitama 338)
るため, 型自体の表面には所要のパターンを反転 した模様が彫られていなければならない。しかし ながら天然模様を彫刻することは不可能であり, 本物模様からの何らかの転写方法による他はない。 プラスチック成形品の高度化と共に天然模様が採 用される機会は増えており，さらに転写表面につ いても，その品質についてはますます高度なもの が要求される。

転写による型製作法として簡便なすのは，樹脂 の流し込みによる樹脂型であるが, 専ら真空成形 型として用いられている。また厚めっきによる電 鋳型む, 真空成形やスラッシュ成形に用いられる あのの, 型製作に長時間を要し, 射出成形型とし ては強度的にも問題があるとされる。溶射型につ いても溶射材料が軟質材に限られるため, 耐久型 には不適とされている。鋳造型としてはショウプ ロセスや石こう型鋳造によるZn合金やAl合金が あるが, 表面加飾型としては転写性に問題がある とされている。鋳造型として精度之耐久性の面で 満足ゆくあのとしてベリリウム銅型がよく知られ ているが価格が高価で特殊な材料であるため誰で あ製造できないのが難点とされている。

\section{2. 真空成形用通気性セラミック型}

\section{1 従来型}

プラスチックシートの真空成形型ではしばしば 


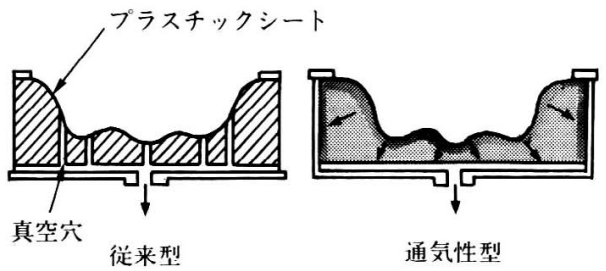

図 1 真空成形比較

加飾表面型が用いられ，かつその表面品質には高 度の転写性が要求される。成形型に備えるべき特 性は正確な反転模様を表面にもちかつ多数の空気 抜き孔を有していることが必要である。従来は樹 脂型，溶射型，電鋳型が使用されている。樹脂型 は安価ではあるが熱伝導性が悪いのが問題であり， 電鋳型は製造に長時間を要し，高価となる。いず れの型についても多数の空気抜き孔を配する必要 がある。

\section{2 通気性セラミック型の製造法}

微細な空気抜き孔を図 1 のように型の表面全体 にもつ通気性の型で，かつ表面微細模様が転写さ れていれば真空成形用型としては理想的である。 このような目的のもとに開発されたのが通気性セ ラミック型である。通気性セラミック型の製造法 を図 2 に示す。あらかじめ製品モデルを準備して おき，これを転写して型をつくる点は, 従来型と 同じである。スラリー状にした原料粉末のスリッ プキャスティングを行い乾燥後焼結して型とする。 原料粉末としてはムライト粉と鉄粉を用い,これ をエチルシリケートに混ぜてスラリーとしている。

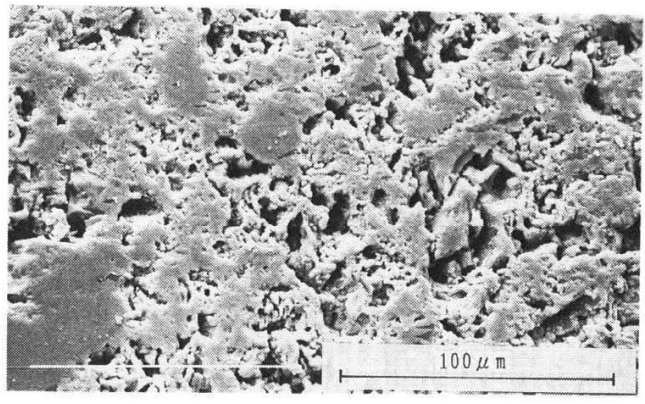

図 3 通気性セラミック型の断面SEM写真

また乾燥体の強度を増すため無機または金属短瀻 維を体積で $2 \%$ \%混入している。

スラリー中のエチルシリケートはその後乾燥お よび焼結工程で除去され図 3 に示すような空孔と して残存し型に通気性を与える。また焼結は空気 中約 $900^{\circ} \mathrm{C} て ゙$ 行われるが，鉄粉は焼結中に酸化し ていわゆる酸化焼結が行われる。焼結による収縮 と酸化焼結による膨張が互いに打ち消し合い，結 果として $0.4 \%$ 以下の膨張に抑えた焼結体が得ら れる。この時酸化焼結による膨張により空孔は減 るものの, 全体として体積で20 30\%の空孔が残 存する。このようにこの型はスリップキャスティ ング法による粉体の焼結体でできている。寸法変 化が少なく結果として通気性が存在するにあかか わらず，かなりの圧縮強度を有する特徽を持つこ ととなる。この型の圧縮強度は約 $700 \mathrm{~kg} / \mathrm{cm}^{2}$ で, 真空成形や圧空成形に対しては十分な強度を有し ている。

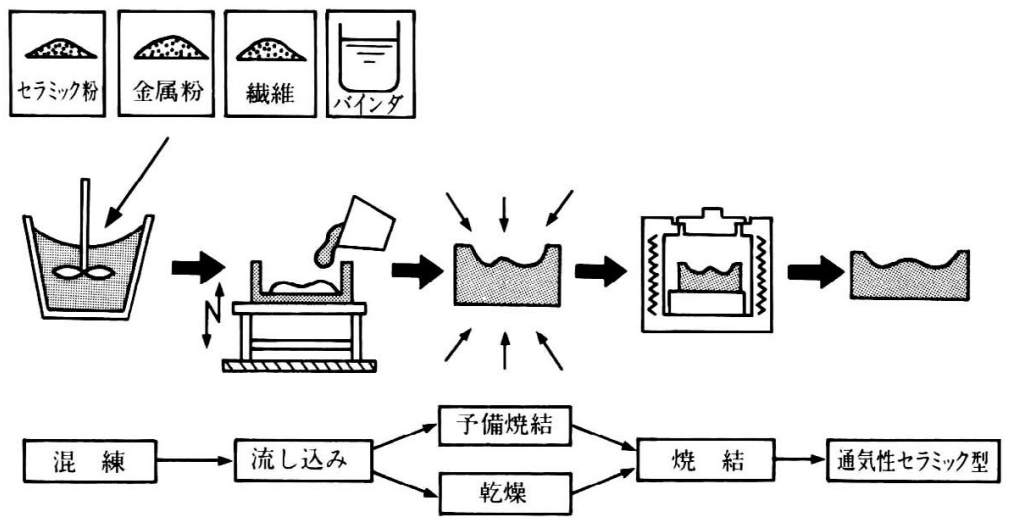

図 2 通気性セラミック型の製作工程 


\section{3 真空成形用通気性セラミック型の特徵}

このようにして製造できる通気性セラミック型 の利点をまとめると以下のようになる。

(1) 天然表面模様

モデル型の表面に天然材を使用することにより， 天然材の表面転写型が得られる。

(2) 微細模様

使用する粉末の粒度を微細化することにより， 表面微細化模様の転写型が得られる。

(3) 高転写性

型全体に通気性を有し，全表面が通気孔に覆わ れているため, 微細模様や深い凹部にわたっても 良好な転写性をむつ。

(4) 高強度

酸化焼結のため多孔質材にもかかわらず，真空 成形に必要とされる十分な強度を有している。

（5）高寸法精度

焼結体にもかかわらず，寸法精度は高く，型と しての使用に問題は少ない。

（6）耐久性

耐摩耗性は高く耐久性は良好である。

（7）低コスト・短納期

モデルが準備された後の製造工程は簡易であり, 型製造は短納期，低コストがはかれる。

（8）同一型の絽返し生産

転写型であるため多数個同時成形型や予備型, 追加型の生産に適している。

一方開発後の問題点として以下の点が指摘され ているが，そのうちいくつかは適切な対策が講じ られている。

（1）低熱伝導性

熱伝導率が低く成形サイクルが遅くなる問題点 があった。これに対してはスリップキャスティン グ時にあらかじめ冷却管を内部に配置することに より，金属成形型並の成形サイクルが得られてい る。

(2) 凸部破損

鋭く突った凸部に圧縮力がかかり成形時に破損 する場合があることに対しては，型の凸部に局部 的に金属を使った内部補強を行うことにより解決 できている。乗用車用ドアトリム成形におけるき め込みを伴なう成形型がそれである。
（3）通気性の劣化

煙が発生するような成形条件下では量産中に空 孔のつまりが認められたが，洗浄または再加熱に より付着物を容易に除去でき再利用できることが 確認されている。

\section{（4）型の修正難}

不注意による型の表面模様の破損に対しては, 手作業で修正せざるを得ないが，大きな損傷に対 しては困難である。この点は他の天然模様の転写 型においても存在する共通問題点である。

（5）高寸法精度型

焼結法による膨張をあらかじめ見込んでおいた としても, 寸法精度の著しく高い型の製作は困難 である。

\section{4 通気性セラミック型の応用}

本来この型は真空成形に開発されたものであり, 応用例はプラスチックシートの真空成形, 圧空成 形が中心である。モデル表面が正確に転写される ことが評価され, 従来の樹脂型では満足できない 主として転写品質の高級なものを中心として使用 されるようになっている。皮しぼやステッチ模様 が多いが，木目や布模様むある。応用例としては, 大きなものはドアトリム，インパネなど車の内装 成形型, 電器OA機器のケース等多岐にわたって いる。特に皮しぼなどでは, 型表面に微細粉末形

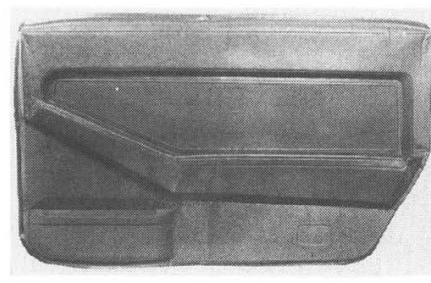

a) ドアトリム

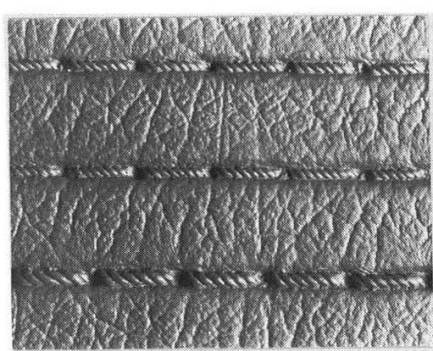

b）皮しぼ,ステッチ

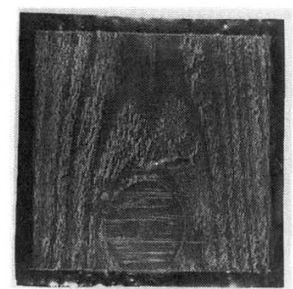

c）木目

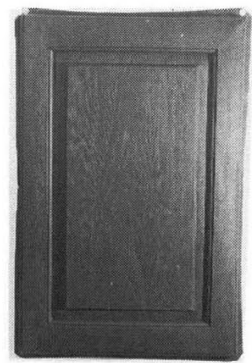

d）木目調ドア
図4 通気性セラミック型による真空成形品例 


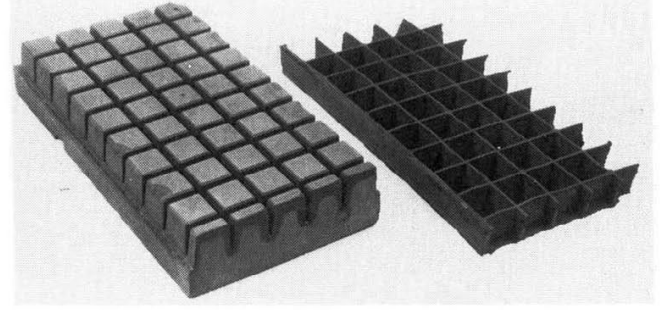

図 5 ゴムの圧縮成形品例

状が残っているためつや消し状の表面が得られ, 一層の高級感が得られる点が評価されている。図 4 に実験的に試作した幾つかの真空成形品の例を 示す。この他通気性が利用できる成形法としては, ゴム成形がある。図 5 に成形例を示すが，ゴムの 圧縮成形では空気抜きが不可欠であり，この型で は型内の空気は自然に抜け出すこととなる。実験 によればゴム成形型としてはやや型強度が不足す るため, 型が破壊しない範囲内で適用可能であり, 表面に微細形状の創生を必要とする成形において は最適な型であろう。

\section{3. 吸引精密鋳造による表面加飾射出成形} 金型

\section{1 吸引精密鋳造による製造法}

さて天然模様を表面にもつ表面加飾成形用射出 成形型としては，専ら電鋳型，ベリリウム銅型が 用いられている。いずれあ高価な金型であり，同 等な金型を早く安価に製造するプロセスの開発が 望まれていた。前節で述べた通気性セラミック型 の型材は金属複合材であり, ある程度の耐熱性を
あっている。この型を鋳型として用い，金属材料 を鋳造することができれば表面加飾した射出成形 用金型として利用できるはずである。あちろんそ の際鋳造により表面模様が微細に転写できる精密 鋳造を行うことが前提である。精密鋳造法として は前述のように鋳型自体の表面の精密模様を確保 すると共に, 鋳造時の精密転写を可能とするため 吸引鋳造を採用する。

金型の製造法を図 6 に示そう。先ずモデルをシ リコンゴムに反転し，このゴム型に通気性セラミッ ク型と同様のセラミックス粉（ムライト粉）と金 属粉（鉄粉）をバインダー（エチルシリケート） で溶いたスラリーを流し込み成形固化する。この 時の鋳型材の成分の一例を表 1 に示す。

\section{2 表面模様の転写状況}

鋳造される型材としては亜鉛合金, $\mathrm{Al}$ 合金, 高力黄銅など鋳造性の良好な金属が適している。 鋳造時の吸引により転写性は著しく向上し, 微細 模様も正確に転写される。図 7 に三角溝の転写状 況を示すが, 無吸引では微細溝がほとんど転写さ れていないのに対し, 吸引鋳造では微細溝のほぼ 完全な転写が実現している。この吸引鋳造ではショ ウプロセスのように鋳型の微細き裂の転写の問題 や, 石こう鋳型のような表面はく離や結晶粒の粗 大化等の表面欠陥の問題も生じないことが確認さ

表 1 鋳型材 料

\begin{tabular}{|c|c|c|}
\hline 材 & 料 & 配 合 率 \\
\hline 鉄 & 鉄 秎：平均粒佳41 $\mu \mathrm{m}$ & $39.4 \mathrm{wt} \%$ \\
\hline \multicolumn{2}{|c|}{ ムライト粉 : 平均粒径 $34 \mu \mathrm{m}$} & $39.4 \mathrm{wt} \%$ \\
\hline \multicolumn{2}{|c|}{ ガラス織維 : $\phi 10 \times 100 \mu \mathrm{m}$} & $4.0 \mathrm{wt} \%$ \\
\hline \multicolumn{2}{|c|}{ バインダー：エチルシリケート } & $17.2 \mathrm{wt} \%$ \\
\hline
\end{tabular}

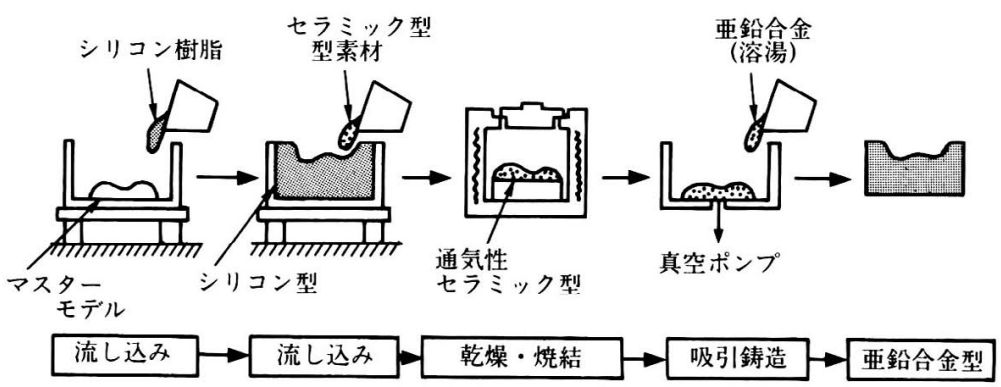

図 6 通気性セラミック型によるプラスチック用表面加飾成形型の製作工程 

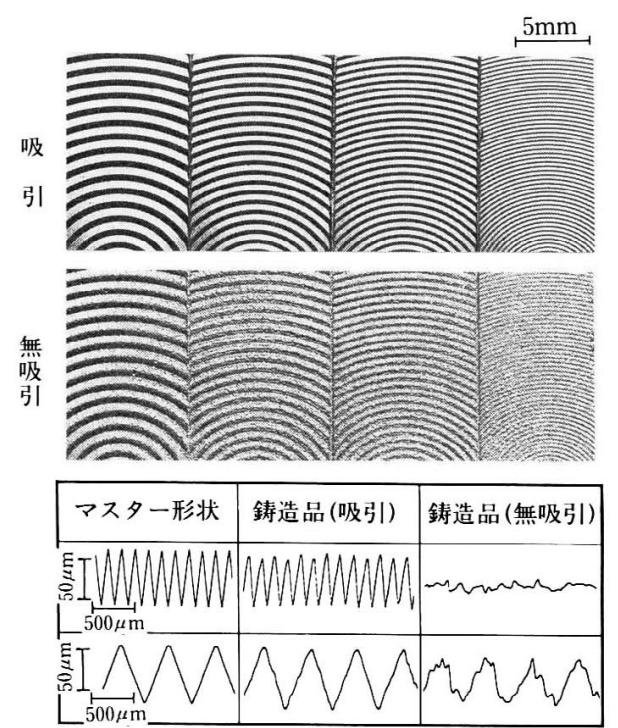

図 7 三角溝の転写状況（材質 : AC $4 \mathrm{D}$ ）

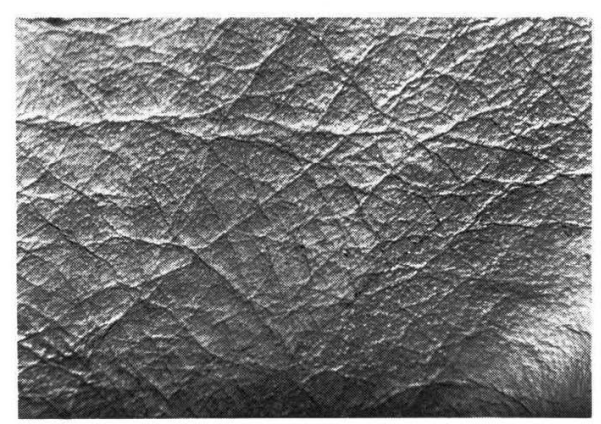

図8 鋳造型の皮しぼ転写状況

れている。

図 8 に鋳造型の皮しぼ表面の状況を示すように， 天然の皮しぼがほぼ完璧に近い状態で金型に転写 されている。これまで鋳造に成功した金型材の硬 さを表 2 に示すが，特に高力黄銅が鋳造できるこ とにより, 鋳造射出成形型の耐久性は大幅に向上 し，さらに鏡面みがき面も量産可能となった。

\section{3 吸引精密鋳造金型の特徵}

今のところこの型は実験的段階といえるが，モ デルから精密転写鋳造によって製造する表面加飾 成形型の特徴を以下に列挙しょう。

（1）表面精密加飾

皮しぼなど天然表面模様を精密に加飾した金型
表 2 各種金型材の硬さ

\begin{tabular}{c|c}
\hline 型 種 類 & 硬さ(HRB) \\
\hline 亜鈶 合 金 (ZAS-C) & 66 \\
アルミ合金 (AC 3 A) & 75 \\
アルミ合金 (AC 4 D) & 116 \\
高力黄 銅 (CMS- 3) & 183 \\
\hline
\end{tabular}

が吸引鋳造により安価にかつ迅速に製造できる。 （2）高耐久性

生産量の多少に応じ金型材質を選択できる。特 に高力黄銅型を使用すれば大量生産む可能である。 （3）型材として高力黄銅を使用すれば，亜鉛合金 金型などで短いとされていた鏡面みがき面の耐久 性の問題は解決する。

（4）良被削性

これら金型材の被削性はいずれも良好であり， 部分的な表面加工や取り付け部の面や穴加工も容 易である。

これらの金型の用途としてはプラスチックスの 柇出成形, スラッシュ成形, 圧縮成形などが考え られているが, 問題点としては以下のものがあげ られよう。

\section{（1）大物型への適用}

亜鉛合金型については問題は認められなかった あのの, $\mathrm{Al}$ 合金, 高力黄銅型の大物で鋳造欠陥 が生じないかどうかは未確認である。

（2）寸法精度

鋳造における収縮が外径寸法で 1 ～ $3 \%$ 生じ, これを見込んでモデルを製作しなければならない。 また寸法のバラッキ等精度の問題も不明である。

（3）鋳造ノウハウ

新しい鋳造法であり，鋳造法案など鋳造ノウハ ウの収集はこれからの課題である。

\section{4.おわりに}

粉末のスリップキャスティングを行い，これを 利用してプラスチック成形用型を製造するという のは新しい試みである。このセラミック型はいわ ばファインセラミックブームに刺激されて生れた あのと言える。開発当時はセラミックに金属粉を 混入する試みや, 従来は鋳型として考えられてい 
たセラミック型を成形用本型として利用するなど の試みに対し新鮮に受けとめられたものである。 通気性型はプラスチックの真空成形用に実用化さ れているが, 最初の目標は金属鍀造用耐久鋳型之 して開発を進めていたものであり, 開発過程で偶 然のことから通気性がありこれを利用できること がわかったものである。その意味で後半の射出成 形用の鋳造による金型は本来の鋳型の研究に戻る と共に通気性を利用し吸引精密鋳造法を確認した あのである。

この吸引精密鋳造法は今のところ精密表面を得 る最高の鋳造法であり, 金型製造ばかりでなく一 般の鋳造法としての期待も大きい。これらの型製 造法においては, 使用粉末を微細化することによ り, より一層の微細表面をもつ型の製造が可能で ある。型表面の微細化の研究成果の一例として図 9 にレコード盤の表面を転写した型を示す。肉眼 では判別し得ない微細溝の転写むこの程度まで可 能になってきている。今後は鋳造による金型の実 用化をはかると共に, 一般機械部品の精密鋳造の 分野への展開も考えてみたいと思っている。

(1990-3-7 受理)

\section{参考文献}

1) 柳沢 章, 野口裕之, 中川威雄 ; 精密工学会誌, 53, 91 (1987)

2 ) 野口裕之, 小山, 今村正人, 柳沢 章, 中川威雄 ; 型技術，3，(7)，p.146（1988）

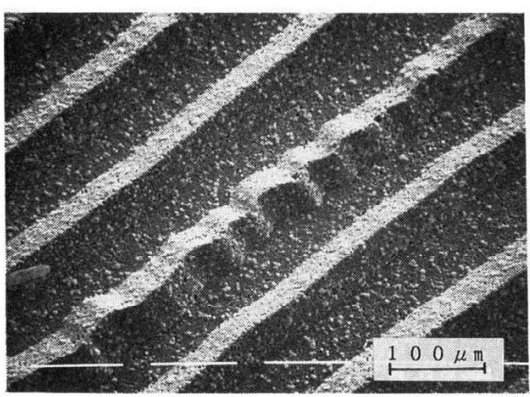

図 9 表面微細化通気性セラミック型

$\left(500^{\circ} \mathrm{C}\right.$ 焼成，マスター：レコード盤）

3 ) 魏 杰, 宮本和彦, 野口裕之, 中川威雄; 型技術, 4, (7), p.130 (1989)

4 ）野口裕之, 魏 杰, 宮本和彦, 中川威雄; 型技術, 4, (7), p.132 (1989)

5）魏 杰, 宮本和彦, 中川威雄, 野口裕之; 1989年 度精密工学会春期大会学術講演会溝演論文集, p. 1017

6) 宮本和彦, 魏 杰, 中川威雄, 今村正人 ; 1989年 度精密工学会春期大会学術講演会講演論文集, p.1019

7 ）魏 杰, 宮本和彦, 野口裕之, 中川威雄 ; 1989年 度精密工学会秋期講演会論文集, p.713

8 ) 宮本和彦, 魏 杰, 今村正人, 中川威雄; プラス チック成形加工学会第 1 回年次大会講演論文集, p.103 (1989)

9）今村正人, 宮本和彦, 魏 杰, 中川威雄 ; 平成元 年度粉体粉末冶金協会講演概要集, p.78

10）野口裕之, 宮本和彦, 魏 杰, 中川威雄; プラス チック成形加工学会第 1 回年次大会講演論文集, p.107 (1989) 